\title{
Influence of Diazotrophic Bacteria on Growth and Biomass Production of Sugarcane invitro
}

\author{
G. M. A. Hossain ${ }^{*}$, A. R. M. Solaiman', A. J. M. S. Karim², \\ G. K. M. M. Rahman ${ }^{2}$ and M. A. B. Mia ${ }^{3}$ \\ ${ }^{1}$ Bangladesh Sugarcrop Research Institute, Ishurdi-6620, Pabna, Bangladesh \\ ${ }^{2}$ Department of Soil Science, Bangabandhu Sheikh Mujibur Rahman Agricultural University, \\ Salna, Gazipur-1706, Bangladesh \\ ${ }^{3}$ Department of Crop Botany, Bangabandhu Sheikh Mujibur Rahman Agricultural University, \\ Salna, Gazipur-1706, Bangladesh \\ *Corresponding author
}

\section{A B S T R A C T}

\section{Keywords}

Influence,

Diazotrophic

Bacteria, Growth,

Biomass, Sugarcane

Article Info

Accepted:

28 February 2020

Available Online:

10 March 2020
An in vitro experiment was carried out at Microbiology Laboratory, Department of soil Science of Bangabandhu Sheikh Mujibur Rahman Agricultural University, Bangladesh to determine the effect of diazotrophic bacteria inoculation on growth and biomass production of sugarcane. Two indigenous diazotrophic bacterial strain isolated from sugarcane rhizosphere i.e. Bacillus cereus (BUSo 13) and Acinetobacter calcoaceticus (BUSo 9) and one reference strain, Azospirillum barsilense (SP 7) collected from ATCC, USA were used to conduct the experiment. Three levels of nitrogen viz., no nitrogen, $50 \%$ nitrogen and $100 \%$ nitrogen were provided for the crop. The results of the experiment revealed that diazotrophic bacterial inoculation in sugarcane increased growth parameters and biomass yield significantly over control. The highest leaf greenness (38.67), number of leaves per plant (9.67), plant height $(76.00 \mathrm{~cm})$, root length $(31.67 \mathrm{~cm})$, dry matter yield $(3.17 \mathrm{~g}), \mathrm{N}$ content in plant $(1.52 \%)$ and $\mathrm{N}$-uptake $\left(48.12 \mathrm{mg} \mathrm{g}^{-1}\right)$ were obtained in treatment $\mathrm{T}_{6}$ receiving $50 \% \mathrm{~N}$ along with Bacillus cereus (BUSo 13) inoculation.

\section{Introduction}

Sugarcane (Saccharum officinarum L.) is one of the world's most important sugar crops, providing over $76 \%$ of the sugar for human consumption. Sugarcane is an exhaustive crop that can uptake great amount of soil nutrients for its biomass production. The use efficiency of applied $\mathrm{N}$ fertilizers in sugarcane applied with recommended dose of $\mathrm{N}$ in the range of
250 to $400 \mathrm{~kg} \mathrm{ha}^{-1}$ is only $20-30 \%$ and hence at every harvest of the crop, soil suffers a net loss of $50-100 \mathrm{~kg} \mathrm{~N} / \mathrm{ha}$. One avenue to remediate the problem associated with synthetic $\mathrm{N}$ fertilizers is the use of microbes capable of biological $\mathrm{N}_{2}$ fixation (BNF) (de Carvalho et al., 2011). Free-livingN $\mathrm{N}_{2}$-fixing bacteria belonging to the genera Beijerinckia, Azospirillum, Azotobacter, Bacillus, Derxia, Enterobacter, and Erwinia appear to be 
frequent colonizers of sugarcane (Dobereiner and Ruschel 1958; Arias et al. 1978; Hegazi et al. 1979; Purchase 1980; Rennie et al. 1982; Graciolli et al. 1983; Seldin et al. 1984). A nitrogen balance study performed by Lima et al (1987) provided direct evidence of a significant contribution of plant associated nitrogen fixation in sugarcane, ranging from 60 to $80 \%$ of total plant $\mathrm{N}$, equivalent to over $200 \mathrm{~kg} \mathrm{~N} \mathrm{ha-1}$ year $^{-1}$. Various classes of bacteria have been reported to improve plant growth and metabolism, known as plant growth promoting rhizobacteria (PGPR). Various strains of Bacillus, Enterobacter, Burkholderia, Acinetobacter, Alcaligenes, Arthrobacter, Azospirillium, Azotobacter, Beijerinckia, Erwinia, Flavobacterium, Rhizobium and Serratia (Rodriguez and Fraga, 1999; Sturz and Nowak, 2000; Sahin et al., 2004) have been identified as PGPR. Serna-cock et al (2011) observed that Azospirillum brasilense and Trichoderma lignorum exercised the greatest effect on stem diameter, root systems, and plant foliation in sugarcane. In a greenhouse study on sugarbeet, three different Bacillus isolates fixed nitrogen and increased growth (Çakmakçi et al., 2006). Similarly, inoculation with a strain of Bacillus sp. also increased growth of roots and shoot parts of rice plants (Beneduzi et al., 2008). In another study, Hafeez et al. (2006) noted that selected Bacillus sp. used as bio-inoculants on wheat resulted in increases in plant biomass, root length, and plant nitrogen and phosphorous content. Dadook et al. (2013) repoted Acinetobacter calcoaceticus as a nitrogen fixing diaztrophs which isolated from asparagus rhizosphere. Previously research studies on Acinetobacter focused on growth potential, indole-3-acetic acid (IAA) production, inorganic phosphate solubilization, and nitrogen fixation (Huddedar et al., 2002; Indiragandhi et al., 2008; Khan et al., 2011b). Acinetobacter calcoaceticus was recently reported as gibberellins producing bacterium (Kang et al., 2009). Two indigenous bacterial strain i.e. Bacillus cereus (BUSo 13) and Acinetobacter calcoaceticus (BUSo 9) have been isolated from sugarcane rhizosphere soil. These two bacteria found to have high potentiality of nitrogen fixation and IAA production. Though Bacillus sp. and Acinetobacter sp. inoculation has beneficial effect on different crops but no works has been done with these bacteria on sugarcane. Therefore, to identify preliminarily their effects on sugarcane growth and biomass yield an in vitro experiment was conducted to observe the influence of diazotrophic bacterial inoculation on growth, biomass yield and nitrogen uptake of sugarcane plant.

\section{Materials and Methods}

An in vitro experiment was carried out to determine the effect of diazotrophic bacteria inoculation on growth and biomass production of sugarcane. The experiment was conducted for eight weeks starting from 05 November, 2011 to 05 January 2012. Two diazotrophic bacterial strain isolated from sugarcane rhizosphere i.e. Bacillus cereus (BUSo 13) and Acinetobacter calcoaceticus (BUSo 9) and one reference strain, Azospirillum barsilense (SP 7), collected from ATCC, USA were used to conduct the experiment. Seedlings from sugarcane bud chips were used in this experiment. Hoagland solution was used to grow sugarcane seedling in test tube. The composition of Hoagland's solution used in this experiment was $\left(\mathrm{mL} \mathrm{L}^{-1}\right)$ : $2 \mathrm{M} \mathrm{KNO}_{3}(2.5), 2 \mathrm{M} \mathrm{Ca}\left(\mathrm{NO}_{3}\right)_{2} \cdot 4 \mathrm{H}_{2} \mathrm{O}(2.5)$, $1.5 \% \quad$ FeEDTA solution (1.5), $2 \mathrm{M}$ $\mathrm{MgSO}_{4} .7 \mathrm{H}_{2} \mathrm{O}$ (1), $1 \mathrm{M} \mathrm{NH} \mathrm{NHO}_{3}$ (1), $1 \mathrm{M}$ $\mathrm{KH}_{2} \mathrm{PO}_{4}$ (pH to 6.0 with $\left.3 \mathrm{M} \mathrm{KOH}\right)(0.5)$ and Minors $\left(\mathrm{H}_{3} \mathrm{BO}_{3}-2.86 \mathrm{gL}^{-1}, \mathrm{MnCl}_{2} .2 \mathrm{H}_{2} \mathrm{O}-1.81\right.$ $\mathrm{gL}^{-1}, \mathrm{ZnSO}_{4} .7 \mathrm{H}_{2} \mathrm{O}-0.22 \mathrm{gL}^{-1}, \mathrm{CuSO}_{4}-0.051$ $\mathrm{gL}^{-1}, \mathrm{Na}_{2} \mathrm{MoO}_{4} \cdot 2 \mathrm{H}_{2} \mathrm{O}-0.12 \mathrm{gL}^{-1}$ ) (Hoagland et al. 1950). Three levels of nitrogen viz., no nitrogen, 50\% nitrogen and $100 \%$ nitrogen 
were provided for the crop. The experiment was laid out in a Completely Randomized Design (CRD) with three replications having 11 treatment combinations. The experimental test tubes were arranged into 3 blocks representing replications to reduce heterogeneous effects. Each block consisted of 11 test tubes and the size of each test tube was $20 \mathrm{~cm}$ x $3.5 \mathrm{~cm}(125 \mathrm{ml})$. All test tubes were placed on a rack made with stainless steel wire (Picture 1).
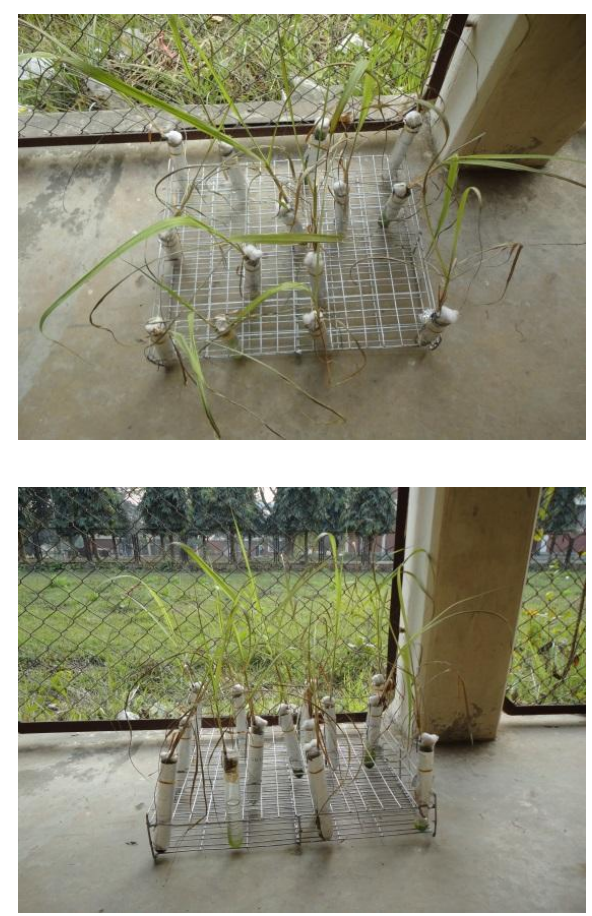

Picture.1 Test-tube placed on rack made with stainless steel wire.

Eleven treatments were considered for the experiment as follows: $\mathrm{T}_{1}$ : Control (no nitrogen), $\mathrm{T}_{2}: 50 \% \mathrm{~N}, \mathrm{~T}_{3}: 100 \% \mathrm{~N}, \mathrm{~T}_{4}: 50 \%$ $\mathrm{N}+$ Acinetobacter calcoaceticus (BUSo 9), $\mathrm{T}_{5}: 50 \% \mathrm{~N}+$ Azospirillum barsilense (SP 7), $\mathrm{T}_{6}: 50 \% \mathrm{~N}+$ Bacillus cereus (BUSo 13), $\mathrm{T}_{7}$ : $100 \% \mathrm{~N}+$ Acinetobacter calcoaceticus (BUSo 9), $\mathrm{T}_{8}$ : $100 \% \mathrm{~N}+$ Azospirillum barsilense (SP 7), $\mathrm{T}_{9}: 100 \% \mathrm{~N}+$ Bacillus cereus (BUSo 13), $\mathrm{T}_{10}: 50 \% \mathrm{~N}+$ mixed inoculums, $\mathrm{T}_{11}: 100 \% \mathrm{~N}+$ mixed inoculums. Bud chips from sugarcane variety Isd 37 were collected for growing seedlings for the experiment. Bud chips were surface sterilized by $70 \%$ ethanol for 30 second and in $3 \%$ $\mathrm{H}_{2} \mathrm{O}_{2}$ for 5 minutes. After that it was washed with sterile water for five times. Then bud chips were placed in sterilized soil in polyethylene bags for germination and maintained in a growth chamber. After germination 30 days old seedlings were used for the experiment (Picture 2).

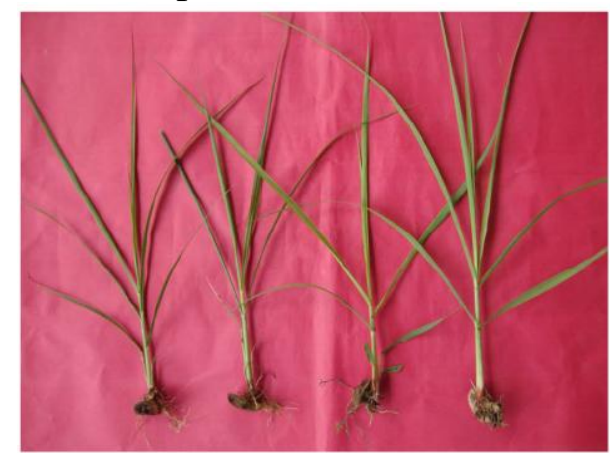

Picture.2 Bud chip seedling

\section{Preparation of inoculums}

Bacterial strains were grown in respective broth for two days. Then the broth was centrifuged at $6000 \mathrm{rpm}$ for 5 minutes. After that supernatants were discarded and cell pellets were washed two times with sterile water and collected in a $30 \mathrm{~mL}$ bottle. These solutions were centrifuged by vortex mixture to homogenize the strains in sterile water. Bacterial concentration was adjusted using a spectrophotometer at $540 \mathrm{~nm}$ and $0.1 \mathrm{ml}$ of suspension containing $10^{8}$ cells were inoculated.

\section{Root soaking with inoculum}

Before inoculation roots of germinated seedlings were surface sterilized with 70 percent ethanol for 30 second and washed several times with sterile distilled water. Roots of germinated seedlings were soaked in the respective bacterial cells for $30 \mathrm{~min}$ for the bacteria to adhere to the roots.

\section{Inoculum application rate}

In each test tube $(20 \mathrm{~cm} \mathrm{x} 3.5 \mathrm{~cm}) 100 \mathrm{~mL}$ 
Hoagland solution containing different nitrogen levels and same amount of other nutrient were added according to respective treatments. Seedlings of sugarcane was placed on a wire ring fitted to the neck of the test tubes. Thus, the rings were placed bellow 3 $\mathrm{cm}$ from the neck of the test tubes. The open end of test tubes was covered with sterilized cotton for avoid contamination. Plantation of bud chip seedlings was done on 05 November, 2011. After two days of planting, $0.5 \mathrm{~mL}$ of inoculums was added into test tubes according to respective treatments. For supplying nutrients, sterilized Hogland solution with respective $\mathrm{N}$ content were regularly added to the test tube according to respective treatments to maintain the initial level of solution. During the study, the rack was regularly placed in a natural condition for giving sunlight to the plants. After four weeks of growth, the same amount of inoculum was added according to respective treatments.

Harvesting was done on 05 January 2012. Mother stalks were selected from each test tube and tagged for collecting data. The entire plants including the shoot and roots were harvested very carefully and data on number of leaves, leaf greenness (SPAD Value), plant height, Root length and biomass yield were recorded soon after harvesting. Leaf samples of sugarcane were dried in an oven at $65-70^{\circ} \mathrm{C}$ for 72 hours and then ground by a grinding machine to pass through a 20-mesh sieve and stored in small paper bags and kept into a desiccator for chemical analysis. The samples were analyzed for nitrogen contents. N contents in the digest were determined following the Micro-Kjeldahl method (Jackson,1973). Nitrogen uptake was calculated by using following formula:

$$
\text { Nutrient uptake }\left(\mathrm{mg} \mathrm{g}^{-1}\right)=\frac{\% \text { Nitrogen } \times \mathrm{Y}\left(\mathrm{g} \mathrm{plant}^{-1}\right)}{100}
$$

Here,

$\%$ Nitrogen $=$ Nitrogen content $(\%)$ of plant $\mathrm{Y}\left(\mathrm{g}_{\text {plant }}{ }^{-1}\right)=$ Total dry matter production of plant

The collected data were compiled and tabulated in proper form and were subjected to statistical analysis by using the computer package Statistix 10 program for Windows Version. Computation and preparation of graphs were done by the use of Microsoft Excel 2003 program.

\section{Results and Discussion}

The influence of diazotrophic bacterial inoculation along with nitrogen on yield contributing characters, biomass yield, nitrogen content and nitrogen uptake by sugarcane plant are presented and discussed bellow.

\section{Number of leaves per plant}

Results presented in Table 1 revealed that number of leaves per plant of sugarcane varied significantly due to different treatments. The highest number of leaves was obtained in treatment $\mathrm{T}_{6}(50 \% \mathrm{~N}+$ Bacillus cereus (BUSo 13) and $\mathrm{T}_{10}(50 \% \mathrm{~N}+$ mixed inoculum) (both 9.67) which was statistically identical with treatments $\mathrm{T}_{3}(100 \% \mathrm{~N})(9.33)$ but superior to the rest of the treatments. The effect of treatment $\mathrm{T}_{3}$ was, however, statistically similar to treatment $\mathrm{T}_{5}$ but this treatment statistically ranked second. The lowest number of leaves per plant was found in control. This result corroborates with that of Serna-Cock et al (2011) who reported higher number of leaves in sugarcane with Azospirillum inoculation. This result was also in harmony with that of Ai'shah et al (2009) who showed higher leaf formation due to diazotrophic bacterial inoculation in oil palm. 


\section{Leaf greenness (SPAD value)}

Inoculation of diazotrophic bacteria along with different levels of $\mathrm{N}$ showed a positive effect on leaf greenness (SPAD value) of sugarcane (Fig. 1). The leaf greenness (SPAD value) ranged from 32.33 to 38.67 . The highest leaf greenness was found in $T_{6}$ (38.67) which was statistically at par with treatment $\mathrm{T}_{10}$ (36.67) and $\mathrm{T}_{3}$ (36.33) but superior to the rest of the treatments. The effect of treatment $\mathrm{T}_{10}$ and $\mathrm{T}_{3}$ were statistically similar to all other treatments except control. The lowest leaf greenness was obtained in control (32.33). This result was in accordance with that of Morais et al (2011) who found significant increase in leaf chlorophyll content with inoculation of mixture of five diazotroph strains in sugarcane. Keyeo et al (2011) reported higher chlorophyll content in rice leaf with inoculation of diazotrophic bacteria.

\section{Plant height}

Plant height of sugarcane responded significantly due to different treatment combinations (Table 1, Plate 3). The highest plant height $(76.0 \mathrm{~cm})$ was obtained in treatment $\mathrm{T}_{6}$ receiving $50 \% \mathrm{~N}$ along with Bacillus cereus (BUSo 13) inoculation whose effect was statistically similar to treatments $\mathrm{T}_{10}(73.0 \mathrm{~cm})$ where $50 \% \mathrm{~N}$ along with mixture of strains was inoculated and $\mathrm{T}_{3}(71.0$ $\mathrm{cm})(100 \% \mathrm{~N})$ but superior to the rest of the treatments. The effect of treatment $\mathrm{T}_{10}$ and $\mathrm{T}_{3}$ were, however, statistically similar to treatment $\mathrm{T}_{5}$ and ranked second. The lowest plant height $(23.0 \mathrm{~cm})$ was obtained in control (no nitrogen). This result corroborates with that of Chakraborty et al (2013) who reported higher cane height with inoculation of diazotroph biofertilizer Azotobacter vinelandii followed by Paenibacillus polymyxa. Khan et al (2010) found higher plant height with inoculation of Azospirillum in mustard.
Solaiman et al (2011) found highest plant height in rice with inoculation of Rhizobium $s p$ isolated from grasspea.

\section{Root length}

Different treatments exerted significant variations in root length of sugarcane plant (Table 1, Picture 3). Root length of sugarcane ranged from $17.00 \mathrm{~cm}$ to $31.67 \mathrm{~cm}$. The highest root length was recorded in treatment $\mathrm{T}_{6}(31.67 \mathrm{~cm})$ which was statistically similar to $\mathrm{T}_{10}(30.33 \mathrm{~cm}), \mathrm{T}_{3}(30.00 \mathrm{~cm}), \mathrm{T}_{5}(29.67$ $\mathrm{cm}), \mathrm{T}_{9}(28.33 \mathrm{~cm})$ and $\mathrm{T}_{8}(27.33 \mathrm{~cm})$ but superior to the rest of the treatments. The effect of treatments $\mathrm{T}_{10}, \mathrm{~T}_{3}, \mathrm{~T}_{5}, \mathrm{~T}_{9}$ and $\mathrm{T}_{8}$ were, however statistically similar to $\mathrm{T}_{4}$ and $\mathrm{T}_{11}$ and ranked second. This result corroborates with that of Paungfoo-Lonhienne et al (2014) who reported stimulated growth of sugarcane plants with diazotrophs Burkholderia australis sp. nov. inoculation. This result was also at par with that of Mia et al (2010) who found higher root length with inoculation of diazotrophs in banana. Solaiman et al (2011) who found highest root length in rice with inoculation of Rhizobium $s p$ isolated from grasspea.

\section{Biomass yield}

The influence of different treatments were found significant in recording biomass yield of sugarcane (Table 1). The biomass yield of sugarcane ranged from 1.42 to $3.17 \mathrm{~g} \mathrm{plant}^{-1}$. The maximum biomass yield (3.17 $\mathrm{g} \mathrm{plant}^{-1}$ ) was obtained in treatment $\mathrm{T}_{6}$ receiving $50 \% \mathrm{~N}$ along with Bacillus cereus (BUSo 13) inoculation, which was followed by $\mathrm{T}_{10}(50 \%$ $\mathrm{N}+$ mixture of inoculum), $\mathrm{T}_{3}(100 \% \mathrm{~N})$ and $\mathrm{T}_{5}(50 \% \mathrm{~N}+$ Azospirillum barsilense). All other treatments except control produced statistically similar biomass yield with that of $\mathrm{T}_{5}$. The lowest biomass yield (1.42 $\left.\mathrm{g} \mathrm{plant}^{-1}\right)$ was obtained in control (no nitrogen). This result corroborates with the findings of 
Muthukumarasamy et al (2006) who reported higher sugarcane biomass yield with half of the recommended dose of nitrogen plus inoculation of Gluconacetobacter diazotrophicus and co inoculation of Gluconacetobacter diazotrophicus and Herbaspirillum sp. Govindarajan et al (2007) found higher biomass yield in sugarcane with inoculation of $G$. diazotrophicus and Klebsiella sp. GR9 along with half recommended dose of nitrogen. Increased biomass yield in sugarcane with inoculation of Azospirillum was also reported by Umrit et al (2005). Solaiman et al (2011) found highest dry matter in rice with inoculation of Rhizobium $s p$ isolated from grasspea.

\section{Nitrogen content in sugarcane plant (\%)}

A significant difference was observed on $\mathrm{N}$ content in sugarcane plant due to inoculation of diazotrophs along with different nitrogen levels (Fig. 4.2). Nitrogen content in sugarcane plant varied from 1.29 to $1.52 \%$. The maximum nitrogen content $(1.52 \%)$ was found in treatment $\mathrm{T}_{6}$ where $50 \% \mathrm{~N}$ along with Bacillus cereus (BUSo13) was inoculated. Whose effect was statistically identical with $\mathrm{T}_{10}, \mathrm{~T}_{3}, \mathrm{~T}_{5}$ and $\mathrm{T}_{9}$ but superior to rest of the treatments. The effect of $\mathrm{T}_{10}, \mathrm{~T}_{3}$, $\mathrm{T}_{5}$ and $\mathrm{T}_{9}$ were, however, statistically similar to treatment $\mathrm{T}_{2}$ and ranked second. The lowest nitrogen content (1.29\%) was obtained in control (no nitrogen). This result was at par with the findings of Hari and Srinivasan (2005) who reported that biofertilizer application along with lower nitrogen level significantly improved nitrogen content of sugarcane stem.

Kim et al (2010) also reported significantly higher nitrogen content in red pepper and rice with inoculation of diazotrophic bacteria Azospirillum brasilense. Govindarajan et al (2007) found higher leaf nitrogen content in sugarcane with inoculation of diazotrophs $G$. diazotrophicus and Klebsiella sp. GR9 along with half recommended dose of nitrogen. Askary et al (2009) found higher $\mathrm{N}$ content in wheat with Azospirillum inoculation.

Table.1 Influence of diazotrophic bacteria on growth and biomass yield of sugarcane

\begin{tabular}{|c|c|c|c|c|}
\hline Treatment & $\begin{array}{c}\text { No. of leaves } \\
\text { plant }^{-1}\end{array}$ & $\begin{array}{c}\text { Plant height } \\
(\mathbf{c m})\end{array}$ & $\begin{array}{c}\text { Root length } \\
(\mathbf{c m})\end{array}$ & $\begin{array}{c}\text { Biomass } \\
\text { (g plant }^{-1} \text { ) }\end{array}$ \\
\hline $\mathbf{T}_{\mathbf{1}}$ & $6.00 \mathrm{e}$ & $23.00 \mathrm{e}$ & $17.00 \mathrm{e}$ & $1.42 \mathrm{~d}$ \\
\hline $\mathbf{T}_{\mathbf{2}}$ & $7.00 \mathrm{de}$ & $56.00 \mathrm{~d}$ & $22.67 \mathrm{~d}$ & $2.17 \mathrm{c}$ \\
\hline $\mathbf{T}_{\mathbf{3}}$ & $9.33 \mathrm{ab}$ & $71.00 \mathrm{abc}$ & $30.00 \mathrm{ab}$ & $2.77 \mathrm{~b}$ \\
\hline $\mathbf{T}_{\mathbf{4}}$ & $7.67 \mathrm{~cd}$ & $59.67 \mathrm{~d}$ & $25.67 \mathrm{bcd}$ & $2.26 \mathrm{c}$ \\
\hline $\mathbf{T}_{\mathbf{5}}$ & $8.33 \mathrm{bc}$ & $65.67 \mathrm{bcd}$ & $29.67 \mathrm{ab}$ & $2.47 \mathrm{bc}$ \\
\hline $\mathbf{T}_{\mathbf{6}}$ & $9.67 \mathrm{a}$ & $76.00 \mathrm{a}$ & $31.67 \mathrm{a}$ & $3.17 \mathrm{a}$ \\
\hline $\mathbf{T}_{\mathbf{7}}$ & $7.33 \mathrm{~cd}$ & $57.67 \mathrm{~d}$ & $24.33 \mathrm{~cd}$ & $2.24 \mathrm{c}$ \\
\hline $\mathbf{T}_{\mathbf{8}}$ & $7.67 \mathrm{~cd}$ & $61.00 \mathrm{~d}$ & $27.33 \mathrm{abcd}$ & $2.28 \mathrm{c}$ \\
\hline $\mathbf{T}_{\mathbf{9}}$ & $8.00 \mathrm{~cd}$ & $62.33 \mathrm{~cd}$ & $28.33 \mathrm{abc}$ & $2.35 \mathrm{c}$ \\
\hline $\mathbf{T}_{\mathbf{1 0}}$ & $9.67 \mathrm{a}$ & $73.00 \mathrm{ab}$ & $30.33 \mathrm{ab}$ & $2.79 \mathrm{~b}$ \\
\hline $\mathbf{T}_{\mathbf{1 1}}$ & $7.00 \mathrm{de}$ & $63.00 \mathrm{~cd}$ & $26.67 \mathrm{bcd}$ & $2.41 \mathrm{c}$ \\
\hline $\mathbf{C V}(\mathbf{\%})$ & 8.74 & 9.45 & 10.53 & 8.05 \\
\hline
\end{tabular}

Means followed by uncommon letters are statistically different from each other at 5\% level of provability by DMRT 
Figure.1 Influence of diazotrophic bacterial inoculation on leaf greenness of sugaracne

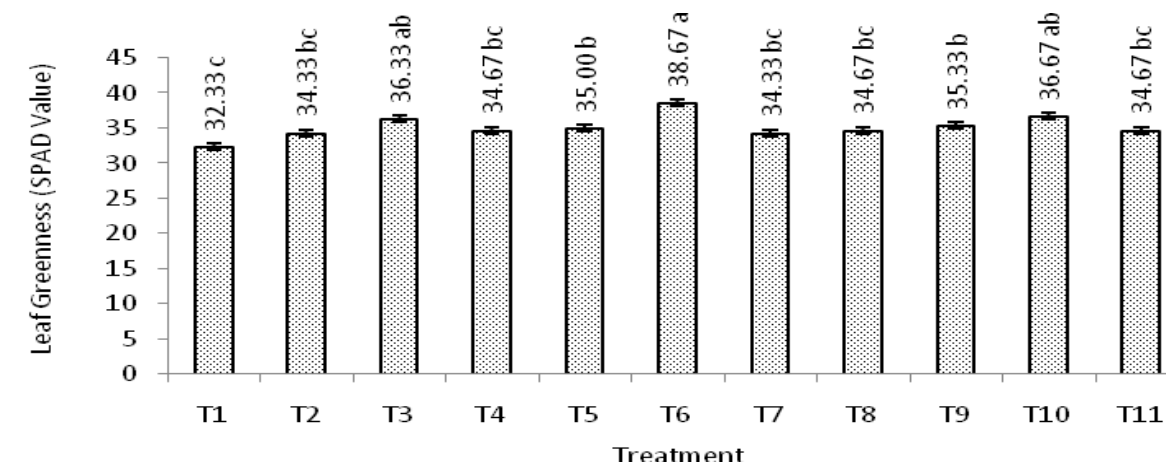

Vertical bars represent standard error of treatment means

Means followed by uncommon letters are statistically different from each other at $5 \%$ level of provability by DMRT

Figure.2 Influence of diazotrophic bacterial inoculation on nitrogen content in sugarcane plant.

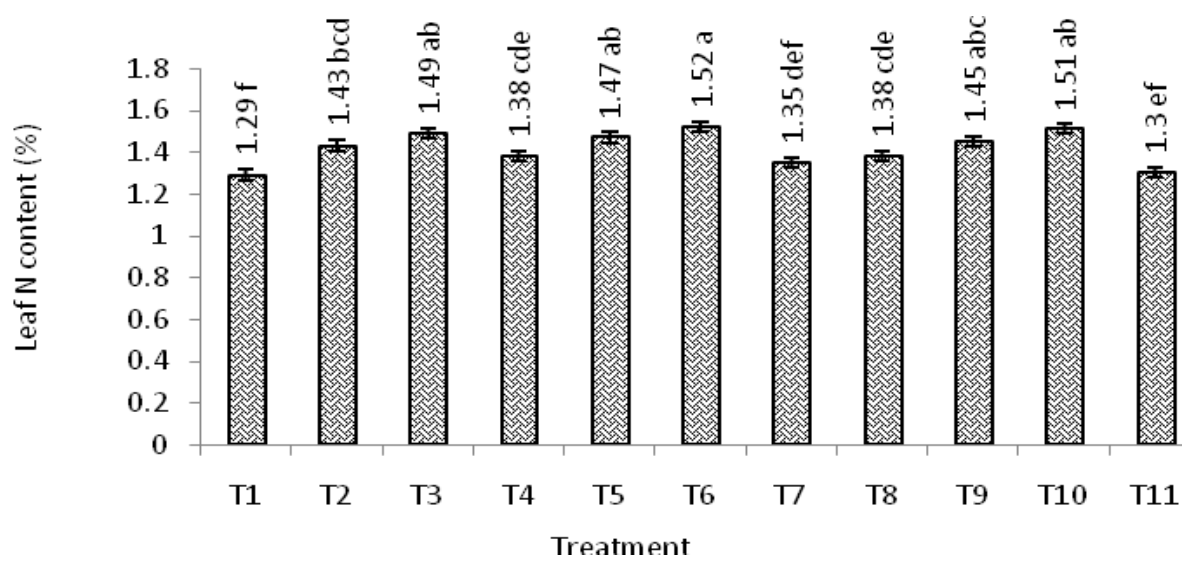

Vertical bars represent standard error of treatment means

Figure.3 Influence of diazotrophic bacterial inoculation on nitrogen uptake in sugarcane plant.

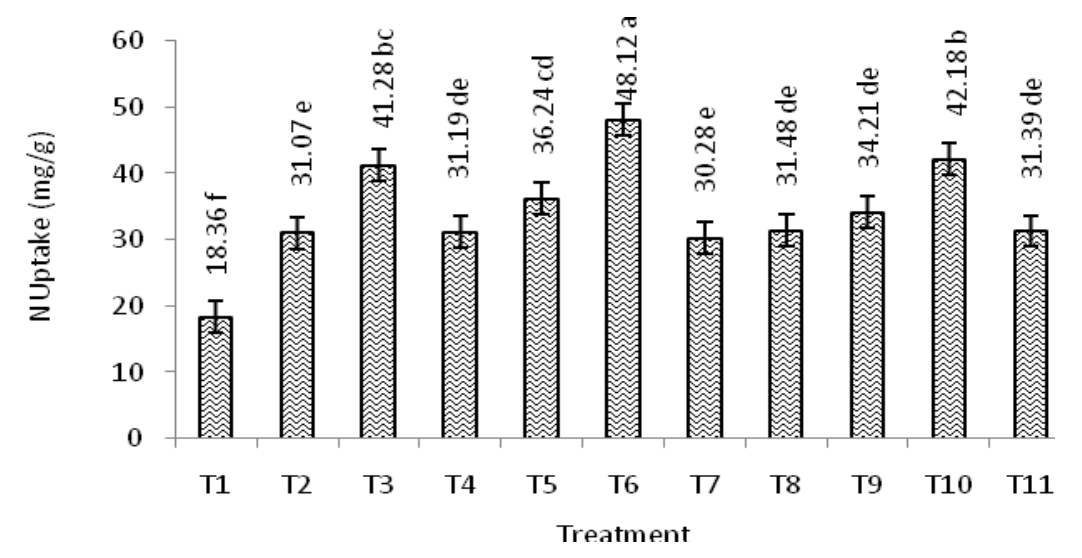

Vertical bars represent standard error of treatment means

Means followed by uncommon letters are statistically different from each other at 5\% level of provability by DMRT 
Picture.3 Root and shoot growth in sugarcane due to diazotriph inoculation

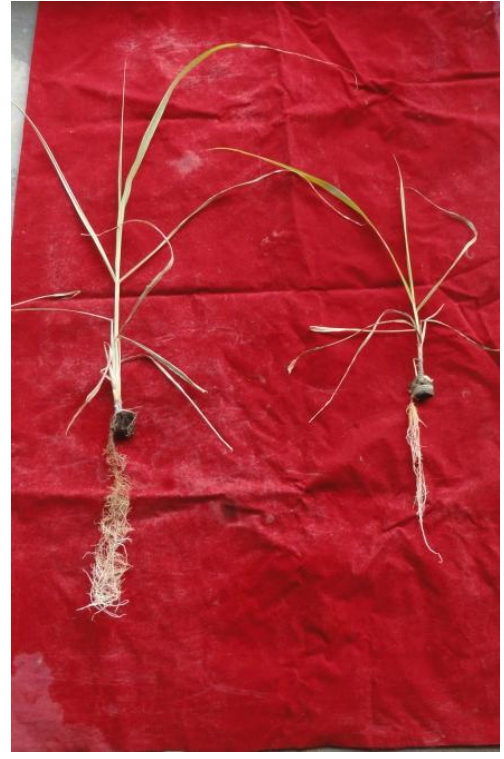

Acinetobacter sp. \& Control

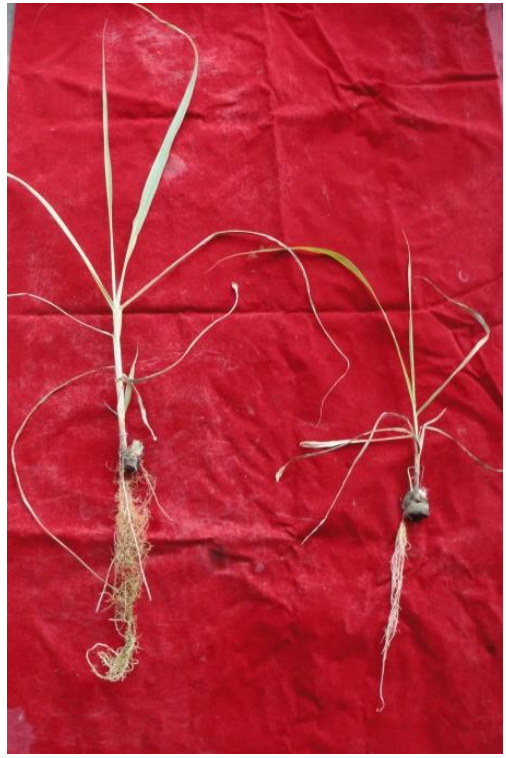

Azospirillum sp \& Control

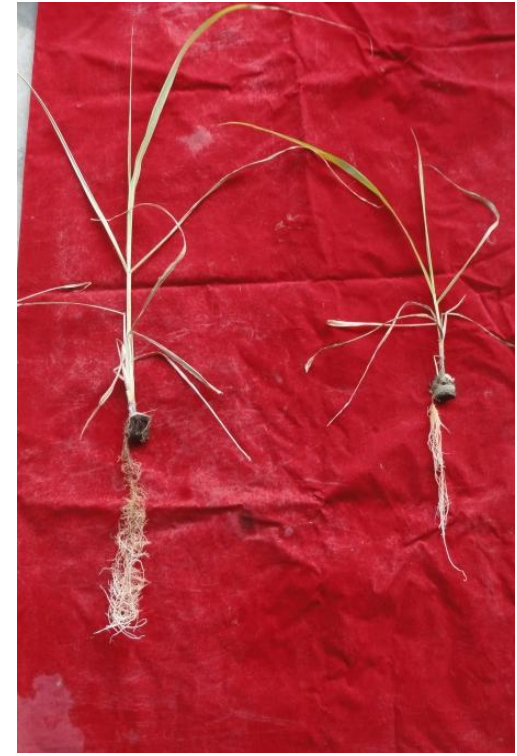

Bacillus sp.\& Control

\section{Nitrogen uptake}

A marked difference was observed in $\mathrm{N}$ uptake by sugarcane plant due to inoculation of diazotrophs along with different levels of nitrogen (Fig. 4.3). Nitrogen uptake by sugarcane plant varied from 18.36 to 48.12 $\mathrm{mg} \mathrm{g}^{-1}$. The maximum $\mathrm{N}$ uptake by sugarcane plant was recorded in treatment $\mathrm{T}_{6}(48.12 \mathrm{mg}$ $\mathrm{g}^{-1}$ ) receiving $50 \% \mathrm{~N}+$ Bacillus cereus (BUSo 13) inoculation which was followed by $\mathrm{T}_{10}(50 \% \mathrm{~N}+$ mixed inoculum $)$ and $\mathrm{T}_{3}$ $(100 \% \mathrm{~N})$. The effect of treatment $\mathrm{T}_{3}$ was, however, statistically similar to treatment $T_{5}$ and ranked $3^{\text {rd }}$.

The lowest $\mathrm{N}$ uptake $\left(18.36 \mathrm{mg} \mathrm{g}^{-1}\right)$ was obtained in control (no nitrogen). This result was in harmony with that of Suman et al (2005) who found increased nitrogen uptake with Gluconacetobacter diazotrophicus inoculation in sugarcane.

The results of the experiment revealed that diazotrophic bacterial inoculation in sugarcane increased growth parameters and biomass yield significantly. The highest leaf greenness (38.67), number of leaves per plant (9.67), plant height $(76.00 \mathrm{~cm})$, root length $(31.67 \mathrm{~cm})$, dry matter yield $(3.17 \mathrm{~g}), \mathrm{N}$ content in plant $(1.52 \%)$ and $\mathrm{N}$-uptake $(48.12$ $\mathrm{mg} \mathrm{g}^{-1}$ ) were obtained in treatment $\mathrm{T}_{6}$ receiving $50 \% \mathrm{~N}$ along with Bacillus cereus (BUSo 13) inoculation. The highest values as observed on these parameters were might be due to production of different growth promoting substances i.e. IAA, hormones and vitamins which influenced photosynthesis, plant height, root elongation and leaf formation which might led to more uptake of nutrients and increased plant growth and biomass yield. Inoculation of Acinetobacter calcoaceticus (BuSo 9) and Azospirillum brasilense(SP 7) in sugarcane was inferior compared to Bacillus cereus (BUSo 13) regarding growth parameter and biomass yield. This might be due to less affinity of Acinetobacter calcoaceticus sp., and noncompatibility of Azospirillum brasilense (SP 7) with local sugarcane variety. Azospirillum brasilense (SP7) strain was collected from USA. Treatment $\mathrm{T}_{10}$ receiving $50 \% \mathrm{~N}$ along with mixture of inoculum also showed statistically similar performance as that of $\mathrm{T}_{6}$ 
$(50 \% \mathrm{~N}+$ Bacillus cereus) regarding growth parameter, biomass yield and nitrogen uptake. Biomass yield increase over control (no nitrogen) and $100 \% \mathrm{~N}$ were found $123.24 \%$ and $14.44 \%$, respectively in treatment receiving $50 \% \mathrm{~N}+$ Bacillus cereus (BUSo 13) inoculation and $96.48 \%$ and $0.72 \%$, respectively in treatment receiving $50 \% \mathrm{~N}+$ mixture of diazotrophs inoculums. The findings of the study corroborate with the work of many researcher. Bacillus is also found to have potential to increase the yield, growth and nutrition of raspberry plant under organic growing conditions (Orhan et al., 2006). Bacterial strain Bacillus cereus when tested in vitro are found to solubilize phosphate and thus helps in growth of plant (Husen, 2003). Garcia et al (2004) reported positive effect of Bacillus lichenoformis on the yield of tomato and pepper. In a greenhouse study on sugarbeet, three different Bacillus isolates fixed nitrogen and increased growth (Çakmakçi et al. 2006). Similarly, inoculation with a strain of Bacillus sp. also increased growth of roots and shoot parts of rice plants (Beneduzi et al. 2008). In another study, Hafeez et al (2006) noted that selected Bacillus sp. used as bio-inoculants on wheat resulted in increases in plant biomass, root length, and plant nitrogen and phosphorous content.

From the above discussion it may be concluded that Bacillus cereus (BUSo 13) or mixture inoculum of Bacillus cereus (BUSo 13), Acinetobacter calcoaceticus (BUSo 9) and Azospirillum brasilense (SP7) inoculation along with $50 \% \mathrm{~N}$ showed better performance compared to other diazotroph treatment combinations regarding growth parameters, biomass yield and nitrogen uptake in sugarcane. Treatment $\mathrm{T}_{6}$ receiving $50 \% \mathrm{~N}+$ Bacillus cereus and treatment $\mathrm{T}_{10}$ receiving $50 \% \mathrm{~N}+$ mixture inoculum performed best in respect of growth parameters, biomass yield and nitrogen uptake in sugarcane.

\section{References}

Ai'shah, O. N., Amir, H. G. Keng, C. L. and Othman, A. R. 2009. Influence of various combination of diazotrophs and chemical $\mathrm{N}$ fertilizer on plant growth and N2 fixation capacity of oil palm seedlings (Elaeisguine ensis Jacq.). Thai J. Agric. Sci., 42(3): 139-149.

Arias, O.E., Gatti, I.M., Silva,D.M., Ruschel, A.P. and Vose, P.B.1978. Primeiras observaciones al microscopioeletronico de bacteriasfijadoras de $\mathrm{N} 2$ en la raiz de la cana de azucar (Saccharum officinarum. L.). Tarrialba, 28: 203-207.

Askary, M., Mostajeran, A., Amooaghaei, R. and Mostajeran, M. 2009. Influence of the Co-inoculation Azospirillum brasilense and Rhizobium melilotiplus 2,4-D on Grain Yield and N, P, K Content of Triticum aestivum (Cv. Baccros and Mahdavi). AmericanEurasian J. Agric. \& Environ. Sci., 5 (3): 296-307

Beneduzi, A., Peres, D., Vargas, L.K., Bodanese-Zanettini, M.H. andPassaglia, L.M.P.2008. Evaluation of genetic diversity and plant growth promoting activities of nitrogen-fixing bacilli isolated from rice fields in South Brazil. Appl. Soil Ecol., 39: 311-320.

Çakmakçi, R., Donmez,F.,Aydın,A. and Sahin,F. 2006.Growthpromotion of plants by plant growth promoting rhizobacteria under greenhouse and two different field soil conditions. Soil Biol. Biochem., 38: 1482-1487.

Chakraborty, D., Sharma, G.D. and Deb, B. 2013.Biofertilizer effect on growth of sugarcane (Saccharum officinarum L.) cultivated in Barak Valley, Assam. Ind. J. Sci., 3 (6): 42-44.

Dadook, M. Mehrabian, S. and Irian, S. 2013.Identification of ten N2-fixing bacteria using $16 \mathrm{~S}$ rRNA and their response to various zinc concentrations. 
Int. J. Cell. Mol. Biotechnol.:1-8, Available online at www.ispacs.com/ijcmb

de Carvalho, T.L.G., Ferreira, P.C.G., and Hemerly, A.S.2011. Sugarcane genetic controls involved in the association with beneficial endophytic nitrogen fixing bacteria. Trop. Plant Biol.,4: $31-41$.

Döbereiner, J., Ruschel, A.P. 1 958.A new species of Beijerinckia.Revista de Biologia, 1: 261-272 (in Portuguese, with abstract in English).

García, J.A.L., Probanza, A., Ramos, B., Palomino, M.R. and Mañero, F.J.G. 2004. Effect of inoculation of Bacillus licheniformis on on tomato and pepper. Agron.Sust. Dev., 24 (Suppl 4): 169176.

Govindarajan, M., Kwon, Soon-Wo and Weon, Hang-Yeon. 2007. Isolation, molecular characterization and growthpromoting activities of endophytic sugarcane diazotroph Klebsiella sp. GR9. World J Microbiol. Biotechnol., 23:997-1006

Graciolli, L.A., Freitas, J.R. and Ruschel, A. P.1983. Bacterias fix adoras de nitrogen ion asraizes, caules e folhas de cana-deacucar (Saccharum sp.). Rev. Microbiol. 14: 191-196.

Hafeez, F.Y., Yasmin, S., Ariani, D., Zafar, Y. and Malik, K. A. 2006. Plant growth promoting bacteria as biofertilizer.Agron. Sustain. Dev., 26: 143-150.

Hari, K and Srinivasan, T. R. 2005.Respose of sugarcane varieties to application of nitrogen fixing bacteria under different nitrogen levels. Sugar Tech, 7 (2\&3): 28-31.

Hegazi, N.A., Eid, M., Farag, R.S. and Monib, M.1979.Asymbiotic $\mathrm{N}_{2}$-fixation in the rhizosphere of sugarcane planted under semiarid conditions of Egypt. Rev. Biol. Soil, 16:23-37.
Huddedar, S.B., Shete, A.M.,Tilekar, J.N., Gore, S.D., Dhavale, D.D. and Chopade, B.A. 2002. Isolation, characterization and plasmid pUPI126 mediated indole-3-acetic acid (IAA) productions in Acinetobacter strains from rhizosphere of wheat. App. Biochem. Biotech., 102- 103: 21-29.

Husen, E. 2003.Screening of soil bacteria for plant growth promoting activities in vitro. Indones. J. Agric. Sci., 4: 27-31.

Indiragandhi, P., Anandham,R. Madhaiyan, M. and Sa, T.M.2008. Characterization of plant growth-promoting traits of bacteria isolated from larval guts of Diamond back moth Plutella xylostella (Lepidoptera: Plutellidae). Curr.Microbiol., 56: 327-333.

Jackson, M.L. 1962. Soil chemical analysis. Prentice Hall Inc. Engle Wood Cliffs, N.J., USA: 55-56.

Kang, S.M., Joo,G.J., Hamayun,M. Na,C.I.,Shin, D.H., Kim,Y.K., Hong,J.K. and Lee,I.J. 2009. Gibberellin production and phosphate solubilization by newly isolated strain of Acinetobacter calcoaceticus and its effect on plant growth. Biotechnol.Lett., 31: 277-281.

Keyeo, F., Shah, O. N. A. and Amir, H. G. 2011. The effect of nitrogen fixation activity and phytohormone production of diazotroph in promoting growth of rice seedlings. Biotechnol., 10(3): 267273.

Khan, A.L., Hamayun, M., Waqas, M., Kang, S.M., Kim, Y.H. Kim,D.K. and Lee,I.J. 2011b. Exophiala sp.LHL08 association gives heat stress tolerance by avoiding oxidative damage to cucumber plants. Biol. Fertil. SoilsDOI 10.1007/s00374011-0649-y.

Khan, I., Masood, A. and Ahmad, A. 2010.Effect of nitrogen fixing bacteria on plant growth and yield of Brassica juncea.J. Phytol., 2(9): 25-27. 
Kim, Ki-Yoon., DekaBoruah, H.P., Kim,Chung-Woo., Shagol, C. C. and Sa, Tong-Min. 2010. Isolation and evaluation of inoculation effect of Azospirillum sp. on growth, colonization and nutrient uptake of crops under green house condition. 19th World Congress of Soil Science, Soil Solutions for a Changing World 1 - 6 August 2010, Brisbane, Australia. Published on DVD.

Lima, E., Boddey, R. M. and Döbereiner, J. 1987. Quantification of biological nitrogen fixation associated with sugarcane using $15^{\mathrm{N}}$ aided nitrogen balance. Soil Boil. Biochem . 19: 165170.

Mia, M.A.B., Shamsuddin, Z.H., Wahab, Z. and Marziah, M. 2010. Effect of plant growth promoting rhizobacterial (PGPR) inoculation on growth and nitrogen incorporation of tissuecultured Musa plantlets under nitrogenfree hydroponics condition. Australian J. Crop Sci., 4(2): 85-90.

Morais, L. K. D., Silva, P.D.E., Areis, V.M., Aguiar, M. S.D., Câmara, T.M.M., Marafon, A.C., Melloivo, W.M.D., Amaral, A.L.D. and Ramos, N.P. 2011. Evaluation of performance of sugarcane genotypes inoculated with endophytic diazotrophic bacteria. Balancing Sugar and Energy Production in Developing Countries: Sustainable Technologies and Marketing Strategies, New Delhi, India, pp 92-95.

Muthukumarasamy, R., Govindarajan, M., Vadivelu, M. and Revathi, G. 2006.Nfertilizer saving by the inoculation of Gluconacetobacter diazotrophicus and Herbaspirillum sp. in micropropagated sugarcane plants.Microbiol. Res., 161 : 238-245.

Orhan, E., Esitken, A., Ercisli, S., Turan, M., Sahin, F. 2006. Effects of plant growth promoting rhizobacteria (PGPR) on yield, growth and nutrient contents in organically growing raspberry.Sci. Hortic- Amsterdam, 111 (suppl 1): 3843.

Paungfoo-Lonhienne, C., Thierry, G.A.L., Yun, K.Y., Richard, I. W., Prakash, L., Cheong, X. C., Lim, P. E., Mark, A. R., Susanne, S. and Philip, H. 2014. A new species of Burkholderia isolated from sugarcane roots promotes plant growth. Microbial Biotechnol.,7(2), 142-154.

Purchase, B.S.1980. Nitrogen fixation associated with sugarcane. In: Proceedings of the South Afr. Sugar Technol.Assoc., pp 173-176.

Rennie, R.J., Freitas, J.R.D., Ruschel, A.P., Vose, P.B.1982. Isolation and identification of $\mathrm{N}_{2}$-fixing bacteria associated with sugarcane (Saccharum sp.). Can. J. Microbiol. 28: 462-467.

Rodriguez, H. and Fraga,R. 1999. Phosphate solubilizing bacteria and their role in plant growth promotion. Biotechnol. Adv., 17: 319-339.

Sahin, F., R. Cakmakci and F. Kantar. 2004. Sugar beet and barley yields in relation to inoculation with $\mathrm{N}_{2}$-fixing and phosphate solubilizing bacteria. Plant Soil., 265: 123- 129.

Seldin, L., Van Elsas, J.D. and Penido, E.G.C.1984. Bacillus azotofixans sp. Nov., a nitrogen fixing species from Brazilian soils and grass roots. Int. J. Syst. Bacteriol. 34: 451-456.

Serna-Cock, L., Arias-Garcia, C. and Hernandez, L. J. V. 2011. Effect of biofertilization on the growth of potted sugarcane (Saccharum officinarum). Biotechnologiaen el Sector Agropecuario Agroindustrial. 9(2): 8595.

Solaiman, A. R. M., Hossain, G. M. A., and Mia, M. A. B. 2011.Effect of Rhizobium on growth and biomass production of rice. Bangladesh J. Microbiol. 28(2): 64-68. 
Sturz, A.V. and J. Nowak. 2000. Endophytic communities of rhizobacteria and the strategies required to create yield enhancing associations with crops. Applied Soil Ecol., 15: 183-190.

Suman, A., Gaur, A. Shrivastava, A.K. and Yadav, R.L. 2005.Improving sugarcane growth and nutrient uptake by inoculating Gluconacetobacter diazotrophicus. Plant Growth Regulation, 47:155-162.

Umrit, G. and Ng KeeKwong, K. F. 2005. Microbial biofertilizers: a source of nitrogen for sugarcane in Mauritius. Mauritius Sugar Industry Research Institute. Web: MAS2005.htm University of Hawaii at Manoa., p. 3155.

\section{How to cite this article:}

Hossain, G. M. A., A. R. M. Solaiman, A. J. M. S. Karim, G. K. M. M. Rahman and Mia, M. A. B. 2020. Influence of Diazotrophic Bacteria on Growth and Biomass Production of Sugarcane invitro. Int.J.Curr.Microbiol.App.Sci. 9(03): 3077-3088. doi: https://doi.org/10.20546/ijcmas.2020.903.353 